\title{
Development and validation of a questionnaire to evaluate teacher training for inclusion: the CEFI-R ${ }^{1}$
}

\author{
Francisca González-Gil $\left({ }^{*}\right)$, Elena Martín-Pastor $\left({ }^{*}\right)$, Begoña Orgaz Baz $\left(^{*}\right)$ y Raquel Poy Castro $\left(^{* *}\right)$ \\ ${ }^{*}$ ) Universidad de Salamanca - España, (**) Universidad de León - España
}

\begin{abstract}
An inclusive teacher is one who considers diversity as a positive feature that enriches education and who, therefore, adapts the teaching methodologies to the learning characteristics of each one of the students and provides support to all their needs. Many research projects emphasize the idea of how students' success depends largely on the teachers' preparation and their competencies and attitudes. The goal of this work is to present the review and resulting modification of an instrument to assess teacher training needs for inclusion (CEFI-R). For this purpose, we used a sample of 202 Spanish teachers with experience in all educational stages (preschool, primary and secondary education). The validation process is described (the process of item inclusion and exclusion, the factorial analysis in order to analyze the structure of the questionnaire and the internal consistency of the scale) which resulted in the development of a 19-item questionnaire grouped into 4 inclusion indicators: conception of diversity, methodology, supports and community participation. We can come to the conclusion that the CEFI-R is a multidimensional tool that allow us to analyze the main aspects in which teachers are less prepared to meet the diverse needs and characteristics of their students.
\end{abstract}

Keywords: Inclusion, inservice teacher education, test validity, questionnaire.

\section{Desarrollo y validación de un cuestionario de evaluación de la formación del profesorado para la inclusión: el CEFI-R}

\section{RESUMEN}

Un profesor inclusivo es aquel que considera la diversidad como una característica que enriquece la educación y que ajusta su metodología a las características de cada uno de sus estudiantes y proporciona apoyo a todos ellos. Muchas investigaciones inciden en resaltar cómo el éxito de los alumnos depende fundamentalmente de la preparación de sus profesores, así como de sus competencias y actitudes. El objetivo de este trabajo es presentar la revisión y consecuente modificación de un instrumento para evaluar las necesidades de formación docente para la inclusión (CEFI-R). Para ello se contó con una muestra de 202 profesores españoles que impartían docencia en educación infantil, primaria y secundaria. Se describe el desarrollo del proceso de validación (inclusión y exclusión de ítems, análisis factorial que nos permite analizar la estructura del cuestionario y consistencia interna del mismo), que ha dado como resultado un cuestionario con 19 ítems agrupados en 4 indicadores de inclusión: concepción de la diversidad, metodología, apoyos y participación de la comunidad. Se concluye que el CEFI-R es una herramienta multidimensional que permite analizar cuáles son los principales aspectos en los que el profesorado está menos preparado para responder a la diversidad de necesidades y características de sus alumnos.

Palabras Clave: Inclusión, formación del profesorado, validación, cuestionario.

\section{Introduction}

In its conclusions on the social dimension of education and training, the Council of the European Union (2010) identified three essential challenges for all the educational systems of the 21st century: (1) social inclusion should, by means of education and training, ensure equal opportunities of access to quality education; (2) it should provide key competences to all students and especially to those who have to deal with educational disadvantages and special needs of support; (3) access to high quality educational opportunities and services should be ensured for all.

In this vein, many investigations emphasize the benefits of inclusion for all students (Dias \& Cadime, 2016; Donnelly

Trabajo financiado por la Fundación Samuel Solórzano de la Universidad de Salamanca [código del proyecto: FS/6-2013]. 
\& Watkins, 2011; Sharma \& Jacobs, 2016) and how its success depends largely on the teachers' preparation, their competencies and attitudes towards teaching in an environment where diversity is a relevant aspect of the students' teaching-learning process. This is also reflected in the McKinsey Report (Barber \& Mourshed, 2007) when considering the quality of the academic personnel as the main explanatory variable of the differences in students' learning. Hattie (2005) coincided with this report, pointing out that the epicenter of students' learning was the faculty. Due to the above, the low rates of training teachers to attend to students' needs and difficulties are related to negative or rejecting attitudes, which are translated into poor teachinglearning strategies and teachers' low expectations for their students (Avramidis \& Kalyra, 2007; Grieve, 2009). In contrast, educators with high levels of self-efficacy in the use of inclusive learning strategies are more prone to make positive changes in their way of teaching (Sharma \& Jacobs, 2016).

However, depending on the teachers' prior university training and on the educational stage they teach, previous investigations find significant differences (Avramidis \& Kalyra, 2007; Colmenero, Pantoja \& Pegajalar, 2015; Kraska \& Boyle, 2014; Sharma \& Jacobs, 2016). These differences emerge around two aspects: (1) professionals with more specialized training in special educational needs (e.g., special education teachers or pedagogues) tend to have a more positive view of inclusion, they feel better prepared to face the challenges posed by this type of education; (2) secondary education teachers are less prone to include students with disabilities or a specific difficulty in their classrooms, partly determined and justified by their scarce pedagogical training.

On another hand, more teaching experience is an explanatory factor of a better predisposition towards implementing inclusive educational models, especially if such experience occurred in contact with students with educational needs and was satisfactory (Ahmmed, Sharma \& Deppeler, 2014; Dias \& Cadime, 2016).

On the basis of the above, we can conclude that the main barriers that prevent schools from truly attending to diversity are the ideas, rules, and beliefs in force in the school, the patterns of functioning, and the agents involved in teaching (Ahmmed et al., 2014; Weiß, Kollmannsberger, Lerche, Oubaid \& Kiel, 2014). In a similar vein, in her study on teachers' attitudes, Grieve (2009) divided teachers into three groups: those who taught inclusively if they had the necessary support, those who considered that inclusion can harm students who have no difficulties, and lastly, those who thought that students who have difficulties due to social, emotional, or behavioral causes require higher quality support than regular schools can offer. In this regard, based on the evidence collected from research on inclusion, Molina and Holland (2010) underline the role of the teaching staff as essential to promote the benefits of inclusive education, a task in which positive teachers' attitudes play a key role, and training constitutes an essential context for their development. However, these authors later point out that precisely the lack of training in this field is one of the main difficulties. In fact, Florian (2012)- in a reflective analysis on the effects of the Inclusive Practice Project (IPP) in Scotland as a national macro-project for the training of primary and secondary teachers- indicates that inclusive education is the backbone of any teachers' training process.

The European Agency for Development in Special Needs Education $(2011,2012)$ determined that some of the competences that teachers should have in order to work with and promote inclusive education are: valuing and supporting the progress of all the students, teamwork, using various teaching methods, encouraging active and participatory learning experiences, and diversifying the teaching content and assessment methods.

Therefore, we define an inclusive teacher as one who considers diversity as a positive feature that enriches education and who, therefore, adapts the teaching methodologies to the learning characteristics of each one of the students and provides support to all their needs. All of this is done with the participation and collaboration of all the involved agents (families, professionals, and environment).

In this context, and in order to analyze whether the faculty is prepared to deal with the demands of an inclusive school, various instruments have been developed, at the national and international level (see Table 1).

Table 1.

Description of the instruments related to assessment of teacher training for inclusion

\begin{tabular}{|c|c|c|c|}
\hline INSTRUMENT & DESCRIPTION & RESPONSE SCALE & TARGET \\
\hline $\begin{array}{l}\text { MATIES- Multidimensional Attitudes } \\
\text { toward Inclusive Education Scale } \\
\text { (Mahat, 2008) }\end{array}$ & $\begin{array}{l}18 \text { items, } 3 \text { factors: } \\
\text { - Cognitive } \\
\text { - Affective } \\
\text { - Behavioral } \\
\end{array}$ & 6-point Likert-type scale & $\begin{array}{l}\text { Teachers of primary and } \\
\text { secondary education }\end{array}$ \\
\hline $\begin{array}{l}\text { CUNIDIS- Cuestiones sobre } \\
\text { Universidad y Discapacidad } \\
\text { [University and Disability Issues] } \\
\text { (Rodríguez \& Álvarez, 2013) }\end{array}$ & $\begin{array}{l}40 \text { items, } 4 \text { factors: } \\
\text { - Curricular adaptations } \\
\text { - Teaching practice } \\
\text { - Accessibility } \\
\text { - University community }\end{array}$ & 5-point Likert-type scale & $\begin{array}{l}\text { University professors and } \\
\text { students }\end{array}$ \\
\hline $\begin{array}{l}\text { SACIE-R- The Sentiments, Attitudes, } \\
\text { and Concerns about Inclusive } \\
\text { Education Revised scale (Forlin, Earle, } \\
\text { Loreman \& Sharma, 2011) }\end{array}$ & $\begin{array}{l}15 \text { items, } 3 \text { factors: } \\
\text { - Feelings } \\
\text { - Attitudes } \\
\text { - Concerns }\end{array}$ & 4-point Likert-type scale & $\begin{array}{l}\text { Future teachers of all } \\
\text { educational stages }\end{array}$ \\
\hline $\begin{array}{l}\text { TEIP- The teacher efficacy for } \\
\text { inclusive practices scale (Sharma, } \\
\text { Loreman \& Forlin, 2012) }\end{array}$ & $\begin{array}{l}18 \text { items, } 3 \text { factors: } \\
\text { - Effective use of instructions } \\
\text { - Effective collaboration } \\
\text { - Effective behavior management }\end{array}$ & 6-point Likert-type scale & $\begin{array}{l}\text { Future teachers and } \\
\text { in-service teachers of } \\
\text { primary and secondary } \\
\text { education }\end{array}$ \\
\hline $\begin{array}{l}\text { Index for Inclusion Questionnaires } \\
\text { (Booth \& Ainscow, 2011) }\end{array}$ & $\begin{array}{l}70 \text { items, } 3 \text { factors: } \\
\text { - Cultures } \\
\text { - Policies } \\
\text { - Practices }\end{array}$ & 4-point Likert-type scale & $\begin{array}{l}\text { Future teachers of all } \\
\text { educational stages }\end{array}$ \\
\hline
\end{tabular}


However, from our perspective, these instruments are sometimes overly focused on analyzing inclusive aspects, but only of students with a disability and presenting few or no items that appraise a fuller picture of inclusion (i.e., MATIES, CUNIDIS, SATE-R). Others make interesting contributions, but only focus on classroom practices (i.e., TEIP or the Index for Inclusion questionnaires, interesting due to their content and very useful to assess inclusion in a concrete center, but that do not allow the generalization of the results).

In view of this situation and in order to determine the stage of our teachers' training in inclusion, the goal of this work is to present the review and resulting modification of an instrument to assess teachers' training needs in this topic. This will allow us to analyze the aspects in which the teachers are less prepared to attend to the diversity of their students' needs, difficulties, and characteristics, as well as to offer a tool to the scientific community in order to assess these needs.

\section{Method}

\subsection{Participants}

The target population of this study is the teachers who teach in Spanish schools of the autonomous community of Castilla y

Table 2.

Characteristics of the distribution of the sample $(N=202)$
León. We used multistage sampling to select the participants. In the first phase, the population of the schools presenting the following criteria was considered: public-private schools, ruralurban schools, and schools that teach preschool and primary education-secondary education or all the educational stages. In the second phase, we selected teachers of different educational stages from the selected schools, with a different number of years of experience and with different initial university training. We decided to include these selection criteria because they are indicative of significant differences in the performance of inclusive teaching practices. After contacting the headmasters of the centers, $27 \%$ refused to participate, claiming lack of time and excess bureaucracy in their day-to-day work.

Thus, the final sample was made up of 58 schools, most of them public $(70.7 \%)$ and urban $(86.2 \%)$. Regarding the grades considered: $36.2 \%$ taught preschool and primary education, $34.4 \%$ taught secondary education, and $29.3 \%$ taught all the educational stages. From these schools, a total of 202 teachers participated. The main profile of the sample is: female $(69.3 \%)$, aged between 30 and 50 (64\%), belonging to public schools $(69.3 \%)$, teaching in urban schools $(87.1 \%)$, teaching secondary education (53\%), with more than 20 years of teaching experience (34.1\%), and holding a Bachelor's degree (45.5\%). Table 2 describes the distribution of the sample.

\begin{tabular}{|c|c|}
\hline & $\mathrm{N}$ (percentage) \\
\hline \multicolumn{2}{|l|}{ Gender } \\
\hline Male & $62(30.7)$ \\
\hline Female & $140(69.3)$ \\
\hline \multicolumn{2}{|l|}{ Age } \\
\hline Less than 30 years & $12(6)$ \\
\hline Between 30 and 40 years & $58(29)$ \\
\hline Between 41 and 50 years & $70(35)$ \\
\hline Over 50 years & $60(30)$ \\
\hline \multicolumn{2}{|l|}{ Ownership of the educational center } \\
\hline Public & $140(69.3)$ \\
\hline Private & $62(30.7)$ \\
\hline \multicolumn{2}{|l|}{ Geographic location } \\
\hline Rural & $26(12.8)$ \\
\hline Urban & $176(87.1)$ \\
\hline \multicolumn{2}{|l|}{ Educational stage taught } \\
\hline Preschool and Primary Education & $95(47)$ \\
\hline Secondary Education & $107(53)$ \\
\hline \multicolumn{2}{|c|}{ Years of teacher experience (mean: 16.88; standard deviation: 10.197 ; range: 1 - 37) } \\
\hline From 1 to 10 years & $56(32.9)$ \\
\hline From 11 to 20 years & $56(32.9)$ \\
\hline More than 20 years & $58(34.1)$ \\
\hline \multicolumn{2}{|l|}{ Initial training } \\
\hline Preschool teacher & $23(11.4)$ \\
\hline Primary Education teacher & $59(29.2)$ \\
\hline Special Education teacher & $13(6.5)$ \\
\hline Pedagogy & $15(7.4)$ \\
\hline Other degree (Bachelor's degree: teachers of secondary education) & $92(45.5)$ \\
\hline
\end{tabular}




\subsection{Procedure}

We based the elaboration of our questionnaire (CEFI-R) on its prior version- CEFI (González-Gil, Martín-Pastor, Flores, (Jenaro, Poy, Gómez-Vela \& Caballo, 2011) Although we initially obtained interesting results (González-Gil, Martín-Pastor, Flores, Jenaro, Poy, Gómez-Vela \& Caballo, 2014; González-Gil, Martín-Pastor, Flores, Jenaro, Poy, Gómez-Vela \& Caballo, 2013), an in-depth analysis revealed a series of limitations; among the main ones is the problem of social desirability of some items and the length of the questionnaire (a large number of items). In view of this, we decided to thoroughly review the instrument in two stages.

The first stage focused on a new review of the literature on teacher training for inclusion and on the recent instruments that somehow assess aspects which, in our opinion, should be included in the new questionnaire.

With regard to this latter aspect, although we found some potentially useful instruments, as mentioned above, their characteristics led us to rule them out, and renewed our intention to improve our instrument and offer a new version of it.

Regarding the literature, we took two documents as an initial reference. Firstly, the professional profile of the teacher in inclusive education of the European Agency for Development in Special Needs Education (2012) due to the international relevance of its projects and, especially, to the consensus of experts from many countries, on which its publications are based. It presents four values in teaching and learning as a basis for the work of all teachers in inclusive education. Our second reference document was the Index for Inclusion (Booth \& Ainscow, 2002, 2011; Booth, Ainscow \& Kingston, 2006), an obligatory tool of reference in the analysis of inclusion in schools, as well as in its theoretical foundation. It addresses the improvement of schools based on reflection and the evaluation of the schools in three main dimensions: school cultures (relationships, values, and beliefs, deeply ingrained in the educational community), policies (school management and plans or programs that are designed and implemented to change it), and practices (what is taught in the classroom and how the teachers teach and the students learn).

Regarding the above, we continued with the process of reviewing the CEFI, rethinking the initial questionnaire, based on three main tasks: redrafting the items, avoiding statements that incite responses influenced more by social desirability than by the reality about which participants are being asked; reducing the number of items, grouping them by content and eliminating those of similar content; drastically reducing the number of indicators (from 10 to 5) and, therefore, redefining them.

When analyzing concurrently the two reference documents for the theoretical foundation of the questionnaire and the resulting indicators, we observed an intrinsic correspondence between the elements of the first document, the dimensions of the second one, and our indicators, which reinforces, on the one hand, the utility of the two reference documents for the theoretical basis of the questionnaire and, on the other hand, the coherence of the instrument with the theory on which it is based (see Table 3).

Table 3.

Correspondence between indicators

\begin{tabular}{|c|c|c|}
\hline $\begin{array}{l}\text { PROFESSIONAL PROFILE OF THE } \\
\text { TEACHER IN INCLUSIVE EDUCATION }\end{array}$ & $\begin{array}{l}\text { DIMENSIONS AND SECTIONS OF THE } \\
\text { INDEX FOR INCLUSION }\end{array}$ & INDICATORS OF THE CEFI-R \\
\hline $\begin{array}{l}\text { 1- Value the students' diversity: the } \\
\text { differences among students are a resource } \\
\text { and an educational value. } \\
\text { a. The different conceptions of inclusive } \\
\text { education. } \\
\text { b. The teachers' viewpoint of these } \\
\text { differences. }\end{array}$ & $\begin{array}{l}\text { A2: Establishing inclusive values } \\
\text { B1: Developing a school for everyone }\end{array}$ & $\begin{array}{l}\text { 1- Conception of diversity } \\
2 \text { - Organization and functioning of the school }\end{array}$ \\
\hline $\begin{array}{l}\text { 2- Support all the students: teachers expect } \\
\text { the best from all their students. } \\
\text { a. Promote the academic, practical, social, } \\
\text { and emotional learning of all the students. } \\
\text { b. Effective educational approaches in } \\
\text { heterogeneous classes. }\end{array}$ & $\begin{array}{l}\text { A1: Building community } \\
\text { B1: Developing a school for everyone } \\
\text { B2: Organizing support for diversity } \\
\text { C1: Designing a curriculum for everyone. } \\
\text { C2: Orchestrating learning. }\end{array}$ & $\begin{array}{l}\text { 2- Organization and functioning of the school } \\
\text { 3- Methodology } \\
\text { 4- Supports } \\
\text { 5- Community participation }\end{array}$ \\
\hline $\begin{array}{l}\text { 3- Teamwork: collaboration and teamwork } \\
\text { are an essential approach for all teachers. } \\
\text { a. Working with parents and families. } \\
\text { b. Working with a large number of } \\
\text { educational professionals. }\end{array}$ & $\begin{array}{l}\text { A1: Building community } \\
\text { B1: Developing a school for everyone } \\
\text { C1: Designing a curriculum for everyone } \\
\text { C2: Orchestrating learning }\end{array}$ & $\begin{array}{l}\text { 2- Organization and functioning of the school } \\
\text { 3- Methodology } \\
\text { 5- Community participation }\end{array}$ \\
\hline $\begin{array}{l}\text { 4- Permanent professional development of the } \\
\text { teaching staff: teaching is a learning activity, } \\
\text { and teachers accept the responsibility of life- } \\
\text { long learning. } \\
\text { a. Teachers are professionals who need to } \\
\text { think. } \\
\text { b. The teacher's initial training as the basis } \\
\text { of continuous learning and professional } \\
\text { development. }\end{array}$ & $\begin{array}{l}\text { B1: Developing a school for everyone } \\
\text { C1: Designing a curriculum for everyone } \\
\text { C2: Orchestrating learning }\end{array}$ & $\begin{array}{l}\text { 2- Organization and functioning of the school } \\
\text { 3- Methodology }\end{array}$ \\
\hline
\end{tabular}

In the second phase, taking as reference the outcomes of the first phase, the resulting questionnaire was evaluated through two consecutive studies by expert judges, allowing us to reassess it, include the experts' proposed suggestions, redraft some items (which made them more meaningful in themselves and within their indicator) and eliminate others, and revise the definition of each indicator, limiting the information to make them exclusive. The outcome of this process was the CEFI-R, a questionnaire made up of 50 items to assess the 5 above-mentioned indicators of inclusion, which was submitted to a validation process. 
In order to facilitate data collection, we offered the teachers participating in the study two possibilities to complete the questionnaire. On the one hand, it was sent in paper format to the postal address of the school where they worked, or, on the other hand, in the online version, a link was provided to them by e-mail. In any event, the confidentiality, anonymity, and use of the resulting data only for research were guaranteed.

\section{Results}

To arrive at the final version of CEFI-R, preliminary analyses of the 50-item version of the measure were conducted. First, we describe the process of item inclusion and exclusion based on the original 50 items of the measure. Next, the factorial analysis was conducted to analyze the structure of the CEFI-R inventory. We also present the internal consistency of the scale and definitive subscales. Lastly, evidence of the validity of the new reduced version is presented.

\subsection{Exclusion/inclusion of items: Analysis of Items}

The first step in developing the final version of CEFI-R was to compute the correlation between the score on each item and the total score in the corresponding subscale if the item was eliminated. The exclusion criterion was to remove all those items whose correlation with the dimension to which they belonged was $<.40$.

In the indicator Conception of diversity, we eliminated items 3, 17, 26, 44 and 47; the correlations of the remaining items ranged between .407 for Item 2 (I would rather not have students with special educational needs (SEN) in my classroom) and .482 for Item 13 (A child with SEN interrupts the routine of the classroom and disrupts the classmates' learning). In the Methodology indicator, we eliminated items 7, 14, 21 and 45; the remaining correlations ranged between .476 for Item 27 (All the teachers should propose activities in class with different levels of difficulty and demand as a function of the students' needs) and .678 for Item 23 (I know how to adapt my way of evaluating to the individual needs of each student). In the Supports indicator, we eliminated Items 4, 8, 12, 28 and 34; the remaining correlations ranged between .511 for Item 25 (Supports within the regular classroom interfere with the learnings of the rest of the students) and .639 for Items 31 (I think the best way to provide support to students is for the support teacher to enter the classroom, rather than do it in the support classroom) and 37 (I think the support teacher's place is within the regular classroom with each one of the teachers). In the Community participation indicator, we eliminated Items 1, 6, 46 and 48; the remaining correlations ranged between .404 for Item 41 (I believe that the philosophy and tenets of the school concerning inclusion and attention to diversity should be presented in the meetings with the families) and .545 for Item 33 (A close relationship between the faculty and the other educational agents is essential). Lastly, in the Organization and functioning of the school indicator, we eliminated Items 5, $15,20,24,32$ and 43; the remaining correlations ranged between .455 for Item 30 (Some students should be placed in special education centers so they will not undergo rejection in regular schools) and .516 for Item 10 (It is more profitable to educate a student with SEN in a special education center than to modify the organizational and educational proposals of a regular school).

As a result of this analysis, 24 items were removed from the initial measure. Five items corresponded to the indicator of Conception of diversity, 4 items to the indicators of Methodology and Support, 5 items to the Supports indicator, 4 items to the Community participation indicator, and 6 items to the indicator of the Organization and functioning of the school. The remaining items were submitted to factor analysis in the next phase.

\subsection{Analysis of the structure of the questionnaire: Factor Analysis}

Exploratory Factor Analysis was conducted to investigate the structure of the CEFI-R inventory (Hoyle \& Duvall, 2004; Bandalos \& Finney, 2010).

In the prior analyses, we checked that Kaiser-Meyer-Olkin value was .82 , exceeding the recommended value of .60 , and that Bartlett's Sphericity Test reached statistical significance, $\left.c^{2}=1889.96(\mathrm{df}=300), \mathrm{p}<.001\right)$, supporting the factorability of the correlation matrix.

Principal axis factoring (PAF) was conducted to establish the suitability of items and the underlying structure of the CEFI-R. As the facets of the scale were expected to be interrelated and not orthogonal, oblique rotation was used. Factors were extracted based on eigenvalues $>1$ and review of the screen plot. In the initial PAF, which included 26 items, five factors were extracted, explaining $22.72,11.62,10.97,6.80$, and $4.27 \%$ of the variance (a total of $52.12 \%$ ). Upon inspecting communalities, it was shown that the percentage of explained variance in the items was acceptable, with loadings above .30, with 30.0 to $63.0 \%$ of explained variance for each of the 25 items.

The rotated solution is depicted in Table 4. We included the items that loaded high on an indicator $(>.40)$. A solution of four factors was extracted, explaining a total of $46.68 \%$ of the variance). We removed the last factor because, after rotation, its eigenvalue was $<1$. However, we adopted the criterion of eliminating from an indicator the items that initially had not been included in that indicator by the authors.

Table 4 .

Factor Loadings for Items

\begin{tabular}{|c|c|c|c|c|c|}
\hline Items & $\begin{array}{c}\text { Factor } 1 \\
\text { Conception of } \\
\text { diversity }\end{array}$ & $\begin{array}{c}\text { Factor } 2 \\
\text { Methodology }\end{array}$ & $\begin{array}{c}\text { Factor } 3 \\
\text { Supports }\end{array}$ & $\begin{array}{c}\text { Factor } 4 \\
\text { Community } \\
\text { participation }\end{array}$ & $\begin{array}{c}\text { Factor } 5 \\
\text { Organization } \\
\text { and functioning } \\
\text { of the school }\end{array}$ \\
\hline Item 19 & & & & .759 & \\
\hline Item 22 & & & & .680 & \\
\hline Item 33 & & & & .658 & \\
\hline Item 39 & & & & .615 & .493 \\
\hline Item 9 & & & & .553 & \\
\hline Item 23 & & .829 & & & \\
\hline Item 16 & & .812 & & & \\
\hline
\end{tabular}




\begin{tabular}{|c|c|c|c|c|c|}
\hline Items & $\begin{array}{c}\text { Factor } 1 \\
\text { Conception of } \\
\text { diversity }\end{array}$ & $\begin{array}{c}\text { Factor } 2 \\
\text { Methodology }\end{array}$ & $\begin{array}{l}\text { Factor } 3 \\
\text { Supports }\end{array}$ & $\begin{array}{c}\text { Factor } 4 \\
\text { Community } \\
\text { participation }\end{array}$ & $\begin{array}{c}\text { Factor } 5 \\
\text { Organization } \\
\text { and functioning } \\
\text { of the school }\end{array}$ \\
\hline Item 40 & & .791 & & & \\
\hline Item 11 & & .693 & & & \\
\hline Item 49 & & .625 & & & \\
\hline Item 38 & .661 & & & & \\
\hline Item 13 & .619 & & & & \\
\hline Item 36 & .585 & & & & \\
\hline Item 42 & .570 & & & & \\
\hline Item 2 & .508 & & & & \\
\hline Item 37 & & & .844 & .415 & \\
\hline Item 31 & & & .785 & & \\
\hline Item 18 & & & .598 & & \\
\hline Item 35 & & & .598 & & \\
\hline \multicolumn{6}{|c|}{ Items eliminated from the final version } \\
\hline Item 41 & & & .400 & .575 & \\
\hline Item 27 & & & & .559 & \\
\hline Item 25 & .621 & & .504 & & \\
\hline Item 10 & .580 & & & & \\
\hline Item 29 & .456 & & & & \\
\hline Item 30 & .525 & & & & \\
\hline Item 50 & .425 & & & .408 & \\
\hline Eigenvalues & 2.32 & 2.60 & 1.29 & 5.38 & 0.55 \\
\hline$\%$ variance explained & .892 & 9.99 & 4.96 & 20.69 & 2.12 \\
\hline
\end{tabular}

Note: loadings between -.40 and .40 are not included in the table.

Factor 1 was labeled Conception of diversity, and five items loaded positively on this factor. The items reflected the teachers' position towards students with special educational needs (students with SEN): "I would prefer not to have them in the classroom" (Item 2), "They disrupt others' learning" (Item 13), "They cannot follow the curriculum" (Item 38) and "They increase the teacher's workload" (Item 42). Item 29 was removed from this indicator, and Item 36 ("We should not accept students with special educational needs in regular schools until we have adequate training for this purpose") was included because its factor loading was higher and its content was more concrete and consistent with the definition of the indicator. We excluded Item 25 (Support factor) and Items 10, 30, and 50 (Organization and functioning of the school factor).

Factor 2 was labeled Methodology and contained five items with positive loadings (Items 11, 16, 23, 40 and 49). These items were designed to assess the adaptation of the methodologies to students' characteristics: the teaching (Item 11), didactic units (Item 16), assessment (Item 23), materials (Item 40), and communication techniques (Item 49).

Factor 3 was labeled Supports and it had four items with positive loadings (Items 18, 31, 35 and 37). These items were designed to assess the way to offer support: collaboration among teachers (Item 18), in the regular classroom (Item 31), support teacher working with everyone (Item 35), and support teacher in the regular classroom (Item 37). Item 37 was maintained although it also cross-loaded on a different indicator because it presented a higher loading on this factor.
Factor 4 was labeled Community participation. Five items loaded positively on this factor and they correspond to the items included in this factor by the authors of the scale (Items 9, 19, 22, 33 and 39). These loadings identified a factor that reflected the participation of the diverse agents in the educational process: "The educational project should be reviewed with the participation of the diverse agents of the educational community (teachers, parents, students, ....)" (Item 9); “The school should promote the involvement of the parents and the community" (Item 19); "Each member of the school (teachers, parents, students, other professionals) is an essential element of the school " (Item 22); "A close relationship between the faculty and the other educational agents (fathers' and mothers' associations, neighbors' associations, school board...) is essential" (Item 33); and "The school should work together with the neighborhood resources (library, social services, health services,...)" (Item 39). Items 39 and 41, corresponding to this dimension, had important loadings on another dimension; we decided to eliminate Item 41 but maintain Item 39, because its loading on this dimension was higher. We eliminated Item 27 (Methodology factor) and Item 50 (Organization and functioning of the school factor).

In summary, the initial pool of the CEFI-R items revealed a multidimensional scale with one indicator less than those originally proposed in the CEFI-R (Organization and functioning of the school indicator). Moreover, a reduction in the number of items that assess each of the remaining dimensions was proposed. 


\subsection{Internal Consistency: Reliability analysis}

Once a good fit of the model was determined, the researchers examined the degree of internal consistency using Cronbach's alpha. The determination of strong reliability estimates $(\alpha \geq 70)$ were examined for: 1 ) the entire instrument and 2) each indicator.

Cronbach's alphas for the CEFI-R were as follows: with all the items ( $\alpha=.89$ for 50 items) and after factor analysis ( $\alpha=.79$ for 19 items). Results showed good internal consistency even for the reduced version with 19 items. Each factor also showed reliability estimations above the .70 threshold. Cronbach's alpha values ranged from .72 (Conception of diversity) to .86 (Methodology), .78 (Supports) and .77 (Community participation), increasing the alpha values in the reduced version.
3.4. Validity evidence: differences in the indicators as a function of educational stage

Subscale scores were calculated by averaging the items that loaded high on each of four factors.

A mixed ANOVA with a repeated measures factor, the four indicators of the questionnaire, and an inter-factor, educational level, was performed. We found significant differences in the four indicators as a function of educational stage $[F(1,200)$ $=26.50, \mathrm{p}<.001, \eta 2=.12]$; the Educational stage $\mathrm{x}$ Indicators interaction was nonsignificant $[\mathrm{F}(3,600)=1.26, \mathrm{p}=.28]$. After performing the a posteriori tests with Bonferroni adaptation, we found significant differences between the two educational levels in all four indicators. The most important differences were found in the indicators of Concept of diversity and Methodology. As expected, preschool and primary teachers scored significantly higher than secondary teachers in all the indicators assessed in the questionnaire (see table 5).

Table 5.

Descriptive statistics of the indicators of the CEFI-R depending on the educational stage

\begin{tabular}{lccc}
\hline & \multicolumn{3}{c}{ EDUCATIONAL STAGE } \\
\multicolumn{1}{c}{ INDICATORS } & $\begin{array}{c}\text { PRESCHOOL/PRIMARY } \\
(\mathrm{n}=95)\end{array}$ & $\begin{array}{c}\text { SECONDARY } \\
(\mathrm{n}=107)\end{array}$ \\
& $\mathrm{M}(\mathrm{SD})$ & $\mathrm{M}(\mathrm{SD})$ & \\
\hline Concept of diversity & $2.91(0.65)$ & $2.54(0.65)$ & $\begin{array}{c}\mathrm{F}(1,200)=15.50 \\
\mathrm{p}<.001, \eta^{2}=.07\end{array}$ \\
\hline Methodology & & & $\begin{array}{l}\mathrm{F}(1,200)=14.30 \\
\mathrm{p}<.001, \eta^{2}=.07\end{array}$ \\
\hline Supports & $3.20(0.53)$ & $2.88(0.63)$ & $\mathrm{F}(1,200)=6.58$ \\
& & $\mathrm{p}=.01, \eta^{2}=.03$ \\
\hline Community participation & $2.97(0.67)$ & $2.72(0.74)$ & $\mathrm{F}(1,200)=4.74$ \\
& & & $\mathrm{p}=.03, \eta^{2}=.02$ \\
\hline
\end{tabular}

In summary, we propose a scale with 19 items included in a four-dimensional structure: Concept of diversity, Methodology, Supports, and Community Participation, which presents good evidence of reliability and validity.

\section{Discussion}

The purpose of this work was to revise and modify an instrument to evaluate the needs of teacher training for inclusion.

This process began, on the one hand, with the analysis of recent instruments that assess similar aspects as our object of study. On the other hand, we reviewed the literature on teacher training in inclusive education, with initial reference to the documents of the European Agency for Development in Special Needs Education (2012) and the Index for Inclusion (Booth \& Ainscow, 2002, 2011; Booth et al., 2006) due to their international relevance in the analysis and theoretical foundation of inclusion.

As a result, we obtained the CEFI-R, whose psychometric properties were analyzed as detailed in the results. These analyses produced the definitive version of the questionnaire (Appendix), after some modifications of the initial version.

Thus, the number of indicators was reduced from 5 to 4 . Specifically, we eliminated the indicator of Organization and functioning of the school, as it did not provide statistically significant data. Nevertheless, after analyzing the definition and the content of the remaining indicators, as well as the items that are finally included, we confirmed that the relevant information about the organization and functioning of an inclusive school is included within them, especially in Methodology. Thus, besides exclusively defining a methodological choice, decisions about the design and development of the curriculum (methodological strategies, resources, assessment...) have a direct impact on the organization- and therefore on the functioning- of the school in which they are implemented. Hence, although this indicator disappears explicitly from the indicators of the questionnaire, it does not disappear from the content assessed, which is based on the international theoretical principles of inclusion. Thus, the four indicators are defined as follows:

(1) Conception of diversity. This refers to the values, attitudes, and beliefs about what diversity is, which involves students' schooling and the educational policy on diversity, and therefore, how teachers understand inclusive education.

(2) Methodology. This addresses aspects related to the design and development of an inclusive curriculum (didactic units, methodological strategies, resources, communication skills, assessment).

(3) Supports. This provides information about the interpretation of support, the support teacher's role, with which students he/she should work, and where such support should be provided, as well as the importance of teachers' collaboration. 
(4) Community participation. This provides information about the degree of collaboration and involvement of all the educational actors and of the neighborhood resources for the development of educational praxis.

As mentioned above, all this has led to a reduction of the number of items, going from the initial 50 to the current 19. Although it might be concluded that this decrease is the consequence of removing an indicator, the underlying rationale it is that, after analyzing the indicators that contributed less to the composition of the questionnaire, we detected some redundancies in the content of various items. Therefore, we finally included the items of similar content but with better psychometric properties, which contributed more to explaining the key concepts of inclusive education and the training required to carry it out. This means that the number of items that define each indicator has been reduced from 10 to 5 in all of them, except for the dimension of Supports, represented by 4 items

Therefore, we again note the need to assess whether the faculty of Preschool, Primary and Secondary Education has the necessary competences to work from the inclusion perspective. These competences focus on an interpretation of diversity as source of wealth and the practical consequences that endorse this; (a) being capable of addressing both the design and the development of the curriculum from methodological tenets that, based on the elements that conform it (goals, strategies, resources, assessment, etc.), allow them to attend to the individual differences found in their schools and classrooms; (b) considering support as a resource at the service of all the students and, therefore, that support teachers must work within the classroom; and (c) implementing all of the above working in coordination with all the elements of the community. We can conclude that the CEFI-R is a useful tool that will allow us to assess the extent to which teachers have mastered these competences in order to design a training proposal adapted to the real demands of the teaching staff that will provide them with the tools, skills, and necessary abilities with which to perform their teach experience from the viewpoint of inclusion

An initial examination of the results obtained from applying the questionnaire shows that, as in prior research (Avramidis \& Kalyra, 2007; Kraska \& Boyle, 2014; Sharma \& Jacobs, 2016), teachers differ as a function of the educational stage they are teaching. Thus, secondary education teachers obtain lower scores than their colleagues of preschool and primary education. In the case of Spain, this may be due to the fact that the teachers had received less didactic training in general and less training in attention to diversity in particular, because attention to diversity is only taught as a complement to initial teacher training for a short period of time (e.g., a pedagogical adaptation course or a Master's degree for secondary teachers).

\section{Limitations and prospective}

In spite of the significant contribution to the analysis of the needs of teacher training for inclusion by means of the modification and improvement an assessment instrument designed for that purpose, it would be appropriate for future work to expand the sample of participant teachers, guaranteeing the representativeness of the entire sample and of each of the variables of interest: demographic variables (age, gender, initial training/other studies), geographic variables (representativeness of the various provinces), educational stage taught, type of school where they teach, or years of teacher experience.

In this way, we could generalize results and determine the main gaps in teacher training that hinder the development of quality education that would guarantee success for all students, and identify the main factors that affect such training. Moreover, it would allow us to contrast and verify the reliability and validity of the questionnaire.

With regard to future lines of research, although various studies (Avramidis \& Kalyra, 2007; Molina \& Holland, 2010; Colmenero et al., 2015; Dias \& Cadime, 2016; Sharma \& Jacobs, 2016; Lerman, 2017; Soldevilla, Naranjo \& Muntaner, 2017) have shown the relevant role of the faculty, their training, and attitudes for the correct functioning of inclusion, they are not the only agents involved in this process, so we cannot stop here. In this sense, future works should analyze this aspect from the perspective of the students- who, as the direct protagonists of the teaching-learning processes, experience the development of educational practices- in order to determine whether their view corresponds with the difficulties their teachers detect and also with the inclusion canon defended at the theoretical level. In a similar vein, we must not forget the important role of families in the presence, participation, collaboration, and involvement in their children's educational process, such that education should be established as a project shared by the family and the school. The family should have the opportunity to assess the degree to which their children's education really meets their needs. Lastly, we should examine the administration, as the executive and manager of the educational policy that determines the functioning and organization of the educational system. This justifies the integration of the administration in upcoming investigations, so that we can analyze its responsibility in making the system really inclusive.

All the above will provide a vision of the educational reality from all the sectors that comprise it. Only when we achieve a full panoramic, which includes the viewpoint of all of the agents, can we fully know the situation in order to improve it.

\section{Final Conclusion}

The design and validation of an instrument that will allow us to assess the training needs for inclusion is a step towards the construction of a school for all, without exclusion. As mentioned throughout the work, one on the main explanatory factors of students' success is the quality of the teaching personnel and their role in the design and development of the process of teaching-learning. It is therefore inevitable for us to ask whether our teachers are actually trained to take on this challenge, in order to design training programs and resources that lead to better preparation of the teaching personnel. With the CEFI-R, we can identify these needs and adjust both the pre-service and the in-service training to the demands of our educational environment.

\section{References}

Ahmmed, M., Sharma, U., \& Deppeler, J. (2014). Variables affecting teachers' intentions to include students with disabilities in regular primary schools in Bangladesh. Disability and Society, 29(2), 317-331. doi: https://doi.org/10.1 080/09687599.2013.796878

Avramidis, E., \& Kalyra, E. (2007). The influence of teaching experience and professional development on Greek teachers 'attitudes towards inclusion. European Journal of Special Needs Education, 22(4), 367-389. doi: https://doi. org/10.1080/08856250701649989

Bandalos, D. L., \& Finney, S. J. (2010). Factor analysis: exploratory and confirmatory. In G. R. Hancock \& R. O. Mueller (Eds.), 
The reviewer's guide to quantitative methods in the social sciences (pp. 93-114). New York, NY: Routledge.

Barber, M., \& Mourshed, M. (2007). How the world's best performing school systems come out on top. Retrieved from http:// mckinseyonsociety.com/how-the-worlds-best-performingschools-come-out-on-top/

Booth, T., \& Ainscow. M. (2002). Index for Inclusion. Developing leaning and participation in schools ( $2^{\text {nd }}$ ed.). Manchester, UK: CSIE.

Booth, T., \& Ainscow, M. (2011). Index for inclusion. Developing learning and participation in schools ( $3^{\text {rd }}$ ed.). Manchester, UK: CSIE.

Booth, T., Ainscow, M., \& Kingston, D. (2006). Index for inclusion: Developing play, learning and participation in early years and childcare. Bristol, UK: CSIE.

Colmenero, M. J., Pantoja, A., \& Pegajalar, M. C. (2015). Percepciones sobre atención a la diversidad en la formación inicial del profesorado en educación secundaria. Revista Complutense de Educación, 26(1), 101-120. doi: http://dx.doi. org/10.5209/rev_RCED.2015.v26.n1.42616

Council of the European Union (2010). Council conclusions on the social dimension of education and training, 3013 Meeting of the Education, Youth and Culture Council. Brussels: Council of the EU. Retrieved from http://www.european-agency. org/news/news-files/Council-Conclusions-May-2010-socialDimension.PDF/view

Dias, P.C., \& Cadime, I. (2016). Effects of personal and professional factors on teachers' attitudes towards inclusion in preschool. European Journal of Special Needs Education, 31(1), 111-123. doi: https://doi.org/10.1080/08856257.2015.1108040

Donnelly, V., \& Watkins, A. (2011). Teacher education for inclusion in Europe. Prospects, 41, 341-353.

European Agency for Development in Special Needs Education (2011). Teacher education for inclusion across Europe. Challenges and opportunities. Odense, Denmark: Author.

European Agency for Development in Special Needs Education (2012). Teacher education for inclusion. Profile of inclusive teachers. Odense, Denmark: Author.

Florian, L. (2012). Preparing teachers to work in inclusive classrooms: Key lessons for the professional development of teacher educator from Scotland's Inclusive Practice Project. Journal of Teacher Education, 63(4), 275-285. doi: $10.1177 / 0022487112447112$

Forlin, C., Earle, C., Loreman, T., \& Sharma, U. (2011). The sentiments, attitudes, and concerns about inclusive education revised (SACIE-R). Scale for measuring pre-service teachers' perceptions about inclusion. Exceptionality Education International, 21(3), 50-65.

González-Gil, F.; Martín-Pastor, E.; Flores, N.; Jenaro, C.; Poy, R. \& Gómez-Vela, M. (2013). Inclusión y convivencia escolar: análisis de la formación del profesorado. European Journal of
Investigation in Health, Psychology and Education, 2(3), 125 135.

González-Gil, F.; Martín-Pastor, E.; Flores, N. \& Jenaro, C. (2014). Evaluación de la formación para la inclusión en el profesorado de España, Costa Rica y República Dominicana. REICE. Revista Iberoamericana sobre Calidad, Eficacia y Cambio en Educación, 12(3), 27 - 39

Grieve, A. M. (2009). Teachers' beliefs about inappropriate behavior: Challenging attitudes? Journal of Research in Special Educational Needs, 9, 173-179. doi: 10.1111/j.14713802.2009.01130.x

Hattie, J. (2005). What is the nature of evidence that makes a difference to learning? Paper presented at the ACER Conference, Melbourne. Retrieved from http://www.acer.edu.au/ workshops/documents/HattieSlides.pdf

Hoyle, R. H., \& Duvall, J. L. (2004). Determining the number of factors in exploratory and confirmatory factor analysis. En D. Kaplan (Ed.), The SAGE handbook of quantitative methodology for social sciences (pp. 301-315). Thousand Oaks, CA: Sage.

Kraska, J., \& Boyle, C. (2014). Attitudes of preschool and primary school pre-service teachers towards inclusive education. Asia-Pacific Journal of Teacher Education 42(3), 228-246. doi: https://doi.org/10.1080/1359866X.2014.926307

Lerman, Z.M. (2017). Making Science Education Accessible to All. Aula Abierta, 46, 13-16.

Mahat, M. (2008). The development of a psychometrically sound instrument to measure teachers' multidimensional attitudes toward inclusive education. International Journal of Special Education, 23(1), 82-92.

Molina, S., \& Holland, CH. (2010). Educación especial e inclusión: aportaciones desde la investigación. Revista Educación y Pedagogía, 22(56), 31-43.

Rodríguez, A., \& Álvarez, E. (2013). Development and validation of a scale to identify attitudes towards disability in higher education. Psicothema, 25(3), 370-376. doi: 10.7334/ psicothema2013.41

Sharma, U., Loreman, T., \& Forlin, C. (2012). Measuring teaching efficacy to implement inclusive practices. Journal of Research in Special Education Needs, 12, 12-21. doi: 10.1111/j.14713802.2011.01200.x

Sharma, U., \& Jacobs, DT. K. (2016). Predicting in-service educators' intentions to teach in inclusive classrooms in India and Australia. Teaching and Teacher Education, 55, 13-23. doi: https://doi.org/10.1016/j.tate.2015.12.004

Soldevilla, J., Naranjo, M. \& Muntaner, J.J. (2017). Inclusive practices: the role of the support teacher. Aula Abierta, 46, 4956.

Weiß, S., Kollmannsberger, M., Lerche, T., Oubaid, V., \& Kiel, E. (2014). The pedagogic signature of special needs education. European Journal of Special Needs Education, 29 (2), 200-219. doi: https://doi.org/10.1080/08856257.2014.895554 
